\title{
The Elements of Post Colonialism and Cultural Hybridity in David Malouf's Remembering Babylon: A Study
}

\author{
Dr. Pradeep Kumar Debata ${ }^{1}$
}

\author{
Sr. Lect \& Head of English, KIIT Polytechnic, KIIT, Bhubaneswar
}

\begin{abstract}
The present paper wants to decipher that from a post-colonial perspective; Remembering Babylon is a pessimistic assessment of the colonial project; a lament for the missed opportunities which is a meeting of disparate cultures that could provide for humanity. Gemmy's double personality can make a cultural harmony between the aborigines and the whites. But neither the aborigines nor the whites accept Gemmy's identity. Hence it has led to a breakdown of cultural harmony. Thus, the novel can be regarded as participating in the struggle between settler culture and First Nation's people.
\end{abstract}

Keywords: Colonialism, Cultural harmony, Aborigine, Identity, Hybridity .

David Malouf was born in Brisbane in 1934. He was educated at Brisbane Grammar School and the University of Queensland. He lived in Europe from 1959-68, and worked as a relief teacher in London before taking up a permanent teaching position at Birkenhead. He also taught English at the University of Sidney from 1968-77 and later he devoted himself to full-time writing.

The novel Remembering Babylon takes place in the mid $19^{\text {th }}$ century in a remote settlement of Queensland, Australia. One day, while a group of children playing at the edge of the village, a remarkable figure stumbles out of the bush. This dark, unkempt person (Gemmy) turns out to be a white man who had fallen from a ship sixteen years back(when he was a nineteen years old sailor), and thereafter he has been living with an aboriginal tribe in the new land ever since. But on the passage of time, he hardly remembers English language and culture because the present sensibility that he has acquired from the aborigines. Gemmy is, in fact, a victim of colonialism as he has already lost his real identity and the present identity is a borrowed one that often keeps him away from the aborigines' community because he fails to adopt the entire prevailing practices of aborigines. When he is put at gun point he shouts "do not shoot, I am a B-b British object" (p. 5). Here, in this novel, Malouf invokes the reverse impact of colonialism. For the first time, an English man is represented as becoming the victim of colonialism of his own blood.

Gemmy is, however, a quintessence of a man with dual personality who represents the conflict between cultural and physical belonging in the new land. He has become really a product of two cultures but he is not able to attain a permanent identity from both of the cultures. Through the portrayal of Gemmy, the novelist discloses the fact that it is impossible to bridge a fine balance between the settlers and the aborigines. Gemmy's act of crossing the boundary signifies a symbolic meaning that he has the prerogative to cross the man made boundaries with his double identity. His recent encounters with the settlers invoke the reminiscences of the life he has lost springs out to return to him. The present experience with the settlers helps him to relearn some words of the language that he has almost lost. Malouf says: " if he could get the words inside him, as he had soaked mush, the creature , or spirit whatever it was, would come up to the surface of him and take them. It was the words he had to get hold of it. It was the words that would recognize get hold of. He did not want to be taken back. What he wanted was to be recognized. (p.32)"

As a child, Gemmy starts learning his lost language again. He tries there to mingle with the white children to evoke his hidden self and his mother tongue. At first Gemmy crafts a sensation in the settlement and attempts to catch the sympathy of white people so that they may wish to help him, despite his obvious savage mentality. He goes to live with the McIvor family, whose daughter, Janet, and nephew, Lachlan Beattie, are among the children who found him in the beginning. While Mrs. McIvor accepts Gemmy with Christian love, her husband Jock remains skeptical. Gemmy also edifies the children some of the skills he has pursued from the aborigines. Gemmy becomes very close to Lachlan who always endeavors to establish his dominance over Gemmy despite being a child. But being a child, Lachlan's attempt to dominate Gemmy signifies his inborn nature of a typical white colonizer wishing to control over the others. In fact, it soon becomes clear that there are major tensions in the village regarding Gemmy's presence among them. Most of the settlers suspect that Gemmy must be the spy of aborigines. Soon Gemmy has become the symbol of fear to

${ }^{1}$ Corresponding Author: Debatapradeep@Yahoo.Com 
many settlers because they feel a kind of tension in keeping Gemmy among them. Among the European settlers, there are two views of handling the aborigines - one group believes that the black should simply be wiped out and every one of them should be terminated because they are semi-barbarians, worthless and could not possibly become Christians. A second group has a more view. They are of the view that the natives could be tamed so as to be used their servants. They envision themselves as owners of large plantations in the new land.

Representatives of both groups try to win Gemmy's confidence and obtain information. The whites wish to know the whereabouts and plans of the aborigines whereas the aborigines want to get hold the secrecies of whites. He, however, remains silent about these matters although being pleasant and differential towards everyone. An uneasy truce holds until one day two aboriginal people are observed while visiting Gemmy on MacIvor's property. This creates an uproar, which eventually leads even some of the God-fearing whites to commit acts of vandalism to injure Gemmy. The horror that the whites often correlate with the aborigines seems to have fallen on Gemmy and they fear him too. One of them says to Gemmy: "It brought you slap up against a terror you thought you had learned, years back, to treat as childish: the Bogey, the Coal man, Absolute Night, and now here it is, not two yards away, solid and breathing.... (p.42)"

To preserve the peace, the McIvors send Gemmy to live with Mrs. Hutchence, an eccentric woman who lives on the margin of the settlement. However, he soon disappears into the wilderness. At the end of Remembering Babylon, fifty years after Gemmy disappeared, Janet McIvor, now a nun and beekeeper in a convent, looks back on her life and sees the importance of change in her life. Gemmy's violent death also brings changes into her life. Her hobby as a beekeeper gives her immense solace. She metaphorically conveys the meaning that being a benevolent nun her attempts are to form a one hive in the new land for all beings beyond racial, ethnic and cultural discrimination.

In Remembering Babylon, David Malouf goes back to the time of colonization to recreate a captivating narrative that reflects issues of identity, cultural difference, discrimination and colonialism. As a victim of colonization Gemmy has become both white man's fear and burden at once. Regarding this context we can relate to Victor Hugo who rightly expresses about colonialism as "The man who finds his homeland sweet is still a tender beginner; the man for whom each country is as his native soil is already strong; but only the man for whom the whole world is as a foreign land is perfect"(Hugo). In this novel Malouf imaginatively forms a scenario of rural contact, of a coming together of two worlds and explores the impact of the two cultures over each other. Gemmy Fairley is a cultural hybrid, a white man gone 'native' having internalized aboriginal values.

Hybridity refers to the formation of a new 'transcultural' form within the barrier produced by colonization. The term refers to the cross-breeding of two species to form a third hybrid species. Hybridization has multifaceted forms such as linguistic, political, rural, etc. It is the in-between space that carries the burden and meaning of culture. Hybridity signifies cross-cultural exchange. The term'going-native' indicates the colonizer's fear of contamination by absorption into nature, life and customs. It encompasses lapses from European behavior, the participation in native ceremonies or the adoption and even enjoyment of local customs in terms of dress, food, recreation and entertainment. Hybridity is an encounter between the West and other. Hybridity results in impurity, intermingling, and the transformation that comes of new and unexpected combinations of human beings, cultures, ideas, politics, movies and songs.

In Remembering Babylon, the moment when Gemmy perches on the top rail of the fence, shouting "Do not shoot, I am a B-b British object" (p.5) forms the seed of the work. These words uttered by Gemmy are illustrative of subservient role he has always had to play in the interest of self-preservation and substance whereby his subjectivity generated within the pre colonial discourse now enters the ambivalent marginal space between cultures. He is a quintessence of a displaced soul who gets transformed his position from subject into object. The fence on the edges of the empire on which Gemmy perches is symbolic not only of the separation of the civilized and the primitive, but is also a border between two different cultural discourses. The moment when Gemmy sits on the fence establishes him in the role that he occupies throughout as an 'in-between figure' on the fence dividing two cultures.

For the aborigines, Gemmy's story begins when they find an inherent crab-encrusted creature on the shore. He had been a "British Object"until Brit-ish seamen heaved him overboard near the Australian coast in the mid 1840s.Gradually Gemmy finds his way into the aboriginal world, but even there he finds non complete recognition. With the passage of time, Gemmy's coming among them becomes another tale, the accounts of which Gemmy believes while his past life passes into oblivion along with his mother-tongue. Gemmy feels a growing urge to reclaim his past life which is what compels him to enter the white settlers' garrison world. Gemmy is really an intruder into the aborigines' community as well as into the white's community in Australia. The moment he enters white's culture, a discourse from which he has long been excluded, he finds his old language (that his new aboriginal language had replaced) coming back to him. To the whites Gemmy had stepped out of an unknown land. 
The whites offer Gemmy clues to his first memories of Willet, Mosey and the Irish and the children among whom he once swarmed in English sawmill, cleaning nuts and bolts, and eating crusted machine oil as if it were candy. In his life at London, he had been Willet's boy, always at the receiving end of his master's curses. Gemmy is constantly haunted by memories of his past life, while the McIvors cherish pleasant memories of their life in Scotland.

Gemmy, however, yearns for recognition among the whites of the settlement, yet not wishing to be taken back into their midst. In a colonial power structure, the hybrid is always the 'other'. Thus, the hybrid is doomed to remain a fractured, chambered self forever, caught in alterity. Gemmy returns to the natives, denying the whiteness in him for which he would never attain recognition. The colonist's acts of barbarism drive Gemmy out of the settlement in the absence of which he would have always remained a 'white-black' hybrid. Gemmy's going back to the land, which was his mother where the aborigines inhabit, is the first step he takes towards negating his in-betweenness, totally merging with the aboriginal ethos. But Gemmy remains a hybrid in the eyes of those children who first saw him. Malouf's text offers hybridity or 'positive contamination' as a visible identity in its valorization of the positive influence Gemmy yields on some of the settlers.

Gemmy's return to the wilderness is indicative of his acceptance of his 'otherness' and a triumph of the discourse of colonialism. Through persona of Gemmy, the suppressed pre- colonial native culture makes its appearance in a colonizer settlement. Gemmy, the colonial hybrid tends to look upon the colonizer as his model. He mimics the white man as he needs to be recognized. But this 'colonial mimicry' gets him nowhere and he remains a half-breed, a cultural amphibian. Remembering Babylon also portrays a cultural clash. Gemmy imbued with the mysticism and earthcenteredness of the native Australians with whom he has spent sixteen years is no longer 'white'. Gemmy cannot identify with the European culture that was once his by heritage. No wonder he can hardly remember how to speak the English language.

The Europeans, secure in their conviction that the aboriginal people are sub-human savages, cannot even consider treating them as persons. Some of the settlers want to eliminate the blacks completely, while others would prefer simply to run them. Gemmy slowly comes to the realization that to save himself and he must return to his aboriginal "roots". Ironically, this escape does not work an epilogue to the story implies that Gemmy comes to a bad end.

\section{CONCLUSION}

At last, Remembering Babylon can be viewed through the elements of post cultural identity where we do find a strong sense of cultural disparity. A post-colonial perspective has become a pessimistic assessment of the colonial project. It is a lament for the missed opportunities which is a meeting of disparate cultures that could provide for humanity. Gemmy's double personality can make a cultural harmony between the aborigines and the whites. But neither the aborigines nor the whites accept Gemmy's identity. Therefore, it led to a breakdown of cultural serenity. Thus, the novel can best be regarded as the struggle between the first nation's people and the colonizer.

\section{REFERENCES}

[1] Goodwin, Ken. A History of Australian Literature. London: Macmillan, 1986.Print.

[2] Hugo of St. Victor/Edward Said - David Ewick @ themargins.Web. 10 Jan, 2015. Retrieved from http://themargins .net/fps/worksheets/01hugo.html

[3] Indyk, Ivor. David Malouf. London: Oxford UP, 1993.Print.

[4] Malouf, David. Remembering Babylon. New York: Vintage, 1994. Print.

[5] Nelson, Philip. Imagined Lives: A Study of David Malouf. Brisbane: University of Queensland P, 1990.Print.

[6] Spinks, Leo. "Allegory, Space, Colonialism: Remembering Babylon and the Production of Colonial History." Australian Literary Studies 17:2 (1995): 166-74.

[7] James. David Malouf. Brisbane: University of Queensland P, 1990.Print 